\title{
Cytotoxic and genotoxic effects of silver nanoparticle/carboxymethyl cellulose on Allium cepa
}

\author{
Aline A. Becaro - Maria Célia Siqueira • Fernanda C. Puti • \\ Marcia Regina de Moura • Daniel S. Correa • José Manoel Marconcini • \\ Luiz H. C. Mattoso • Marcos David Ferreira
}

Received: 11 October 2016 / Accepted: 9 June 2017 /Published online: 24 June 2017

(C) Springer International Publishing AG 2017

\begin{abstract}
Several mutagenic agents may be present in substances released in the environment, which may cause serious environmental impacts. Among these substances, there is a special concern regarding the widespread use of silver nanoparticles (AgNP) in several products due to their widely known bactericidal properties, including in the medical field and the food industry (e.g., active packaging). The assessment of the effects of AgNP released in the environment, having different concentrations, sizes, and being associated or not to other types of materials, including polymers, is therefore essential. In this research, the objective was to evaluate the genotoxic and cytotoxic effects of AgNP (size range between 2 and $8 \mathrm{~nm}$ ) on root
\end{abstract}

A. A. Becaro · F. C. Puti · D. S. Correa · M. D. Ferreira $(\bowtie)$ Programa de Pós-Graduação em Biotecnologia (PPGBiotec), Centro de Ciências Exatas e Tecnologia, Universidade Federal de São Carlos (UFSCar), São Carlos, SP 13565-905, Brazil e-mail: marcos.david@embrapa.br

A. A. Becaro - M. C. Siqueira · F. C. Puti - D. S. Correa • J. M. Marconcini • L. H. C. Mattoso • M. D. Ferreira Laboratório Nacional de Nanotecnologia para o Agronegócio (LNNA), EMBRAPA Instrumentação, São Carlos, SP 13560-970, Brazil

M. C. Siqueira • D. S. Correa • L. H. C. Mattoso Programa de Pós-Graduação em Química (PPGQ), Centro de Ciências Exatas e Tecnologia, Universidade Federal de São Carlos (UFSCar), São Carlos, SP 13565-905, Brazil

M. R. de Moura

Departamento de Física e Química, UNESP, Ilha Solteira, SP 15385-000, Brazil meristematic cells of Allium cepa (A. cepa). Tests were carried out in the presence of colloidal solution of AgNP and AgNP mixed with carboxymethylcellulose (CMC), using distinct concentrations of AgNP. As a result, when compared to control samples, AgNP induced a mitotic index decrease and an increase of chromosomal aberration number for two studied concentrations. When AgNP was in the presence of CMC, no cytotoxic potential was verified, but only the genotoxic potential for AgNP dispersion having concentration of $12.4 \mathrm{ppm}$.

Keywords Mitotic test - Chromosomal aberration . Silver nanoparticles · Carboxymethylcellulose . Allium cepa

\section{Introduction}

Packaging is indispensable for food preservation purposes by retarding food deterioration, increasing food shelf life, and maintaining food quality and safety. Thus, packaging provides protection against three main external classes of spoilage agents: chemical, biological, and physical (Becaro et al. 2015, Marsh and Bugussu 2007).

Coating fruits and vegetables with biodegradable films based on polysaccharides is of great interest to the packaging field due to increasing demands for enhanced food quality and shelf life. Moreover, coating can be an alternative to non-renewable materials conventionally used for the production of plastic films (Mayachiew and Devahastin 
2010). Carboxymethyl cellulose (CMC) is a cellulose derivative (ether) usually presented in the form of sodium salt, being an anionic polymer that is soluble at low concentrations, biocompatible, biodegradable, and features great film-forming properties. Also, within the percentages in which CMC is typically used (1 to 5\%), it does not cause interference in the sensory properties of the packaged product, being physiologically inert, nontoxic, and widely applied in food and pharmaceutical industries (Hebeish et al. 2013).

One of the promising systems intended to modify the characteristics of polymeric films for food preservation is the incorporation of nanostructures (Shin et al. 2014; Kanmani and Rhim 2014; Moura et al. 2011). Silverbased compounds are among the most promising inorganic antibacterial agents due to their remarkable biocidal effect against several bacteria and fungi. Therefore, these compounds arouse considerable interest in the food packaging field (Becaro et al. 2016; Siqueira et al. 2014; Derbalah et al. 2011).

However, the widespread use of AgNP and other nanostructures in several segments exposes humans and the environment to their effects through inhalation, ingestion, dermic contact, etc ( $\mathrm{Su}$ et al. 2014; Gambardella et al. 2013; Becaro et al. 2015). Toxic compounds, including mutagenic agents, are present in pollutants that are inappropriately released into the environment, leading to severe impacts to the ecosystem. Thus, researches on their effects are highly demanded (Sobeh et al. 2016; Panda et al. 2011; Yu et al. 2013; Juchimiuk and Maluszynska 2005).

Cytotoxicity and genotoxicity tests are widely known and have been used since the 1920 s to evaluate chromosomal aberration frequency of mutagenic potential and chromosomal breakages (Satapathy and Swamy 2013). International and national environmental entities, such as EPA (US Environmental Protection Agency), WHO (World Health Organization), and UNEP (United Nations Environment Programme), recommend the use of plants as test organisms for genetic tests (Ma et al. 1995).

The toxicity test using Allium cepa (A. cepa) was introduced by Levan in 1938 (Fiskesjö 1985) and has been largely used as a tool for environmental monitoring towards distinct micro- and nanomaterials (Leme and Marin-Morales 2009) due to the high sensitivity compared to other organisms tested. The use of A. cepa as test organism is favored by several characteristics such as rapid root growth, low cost, high tolerance to distinguished cultivation conditions, elevated number of cells in division, notable proliferation kinetics, reduced number of large chromosomes, chromosomes in good condition to study damage or disturbances in the division including the assessment of aneuploid risks, as well as easy availability and management (Belcavello et al. 2012; Turkoglu 2012). Therefore, A. cepa has shown outstanding position among the tests recommended by law to assess genotoxic agents (Mateuca et al. 2006). For instance, A. cepa has been used to evaluate the influence of contaminants in water resources (Christofoletti, Pedro-Escher, Fontanetti 2013; Mazzeo et al. 2015), textile effluent (Caritá and Marin-Morales 2008) sand, soil (White and Claxton 2004), fertilizer (Anacleto, Roberto, Marin-Morales 2017), dyes, and petroleum derivatives (Leme and Marin-Morales 2008), heavy metals (Qin et al. 2016; Deng, Wang, Xin 2016; Vargasa et al. 2017; Rajeshwari et al. 2016) and pesticides (Rodríguez et al. 2015).

Cytotoxicity and genotoxicity tests are based on atypical nuclear standard parameters, which consist of an elevated number of cells with heteromorphic pair of nucleoli. The presented results in these tests can be considered as an indicative that the sample represents also a biological threat for other organisms (Fiskesjö 1985). Its high sensibility allows that no contamination is undetected even in complex mixtures. In a study performed by Pakrashi et al. (2014), A. cepa cells were found to present several abnormalities (e.g., chromosomal breakage, alterations in anaphase, and micronuclei formation) upon exposure to $12.50 \mathrm{ppm}$ of $\mathrm{TiO}_{2} \mathrm{NPs}$. The effects of $\mathrm{ZnO} \mathrm{NPs}$ on the mitotic index (MI) and chromosomal aberration index were determined through the hydroponic culturing of A. cepa by Kumari et al. (2011): A. cepa roots were treated with the dispersions of zinc oxide nanoparticles at four different concentrations $(25,50$, 75 , and $100 \mathrm{ppm}$ ). The authors observed that by increasing concentrations of $\mathrm{ZnO}$ NPs, MI decreased with the increase of pycnotic cells, while chromosomal aberration index increased. Therefore, it becomes of prime importance to evaluate the toxicity of nanostructured systems in plant models. For this purpose, this research aimed to evaluate the genotoxic (presence of chromosomal aberration) and cytotoxic (cell death and mitotic index) effects of AgNP (size range between 2 and $8 \mathrm{~nm}$ ) in root meristematic cells of A. cepa. Tests were carried out in the presence of colloidal solution of AgNP and AgNP mixed with 
carboxymethylcellulose (CMC), using distinct concentrations of AgNP.

\section{Materials and methods}

The methodology of the in vivo tests using A. серa seeds to evaluate cytotoxicity and genotoxicity used in this study was based on the procedure proposed by Leme and Marin-Morales (2009). A. cepa L. seeds $(2 n=16)$ were selected and germinated in ultrapure water at ambient temperature $\left(25^{\circ} \mathrm{C}\right)$. After achieving 1.50 to $2.00 \mathrm{~cm}$ in length, the roots were removed from the germination plate, and ten were elected and placed in contact with a colloidal solution of silver nanoparticles of $8-10 \mathrm{~nm}$. The AgNP were synthetized according to Neto et al. (2008) and Mbhele et al. (2003) with concentrations of $1.50 \mathrm{ppm}$ (A) (a less concentrated AgNP dispersion than employed by Pulate et al. (2011) and Kumari et al. (2009)) and 15 ppm (B) (concentration similar to the one employed by Patlolla et al. (2012)) for $24 \mathrm{~h}$, and each vessel contained ten roots (test 1 ).

In test 2, seeds were deposited in contact with a $\mathrm{CMC} /($ AgNP-PVA) film-forming solution with a silver concentration of $1.24 \mathrm{ppm}(\mathrm{C} 1)$ and $12.40 \mathrm{ppm}(\mathrm{C} 2)$ throughout $24 \mathrm{~h}$. Silver nanoparticles were synthetized through a chemical reduction reaction of silver ions (using $\mathrm{AgNO}_{3}$ ) by a reducing agent $\left(\mathrm{NaBH}_{4}\right)$ in the presence of a stabilizing agent (PVA). In order to obtain $\mathrm{CMC} /$ silver nanoparticle (CMC/AgNP-PVA) filmforming solution, $1 \%$ of CMC $(\mathrm{m} / \mathrm{v})$ was added to the silver nanoparticle solution. Ultrapure water was used as negative control, whereas the herbicide trifluralin $(0.075 \mathrm{~g} / \mathrm{L})$ was used as positive control. After $24 \mathrm{~h}$ of contact with the solutions, roots were fixed with the Carnoy reagent (ethyl alcohol and acetic acid at a volume ratio of $3: 1$ ) for $6 \mathrm{~h}$ at room temperature. Once fixed, a new fixing solution was prepared and added and the rootlets were kept under refrigeration. Subsequently to the fixing period, the roots were removed from the reagent, washed with water, and subjected to acid hydrolysis using a $1 \mathrm{~mol} / \mathrm{L} \mathrm{HCl}$ solution at $60^{\circ} \mathrm{C}$ for $9 \mathrm{~min}$. Afterwards, the samples were washed in distilled water and placed in contact with the Schiff reagent for $2 \mathrm{~h}$ in an amber glass flask and in the absence of light. Excess dye was removed with distilled water. The root meristematic region was cut with a stainless steel blade, disposed on a glass slide, added by two drops of $2 \%$ acetic acid carmine, and covered with a cover slip. For the cell count, ten slides of each sample were selected and analyzed under a bright field light microscope with $\times 40$ objective, in which cell divisions and abnormalities based on nucleus and chromosomal characteristics were observed. In these slides, at least 500 cells were analyzed, totaling approximately 5000 cells, which were used to calculate the mitotic index ${ }^{1}$ (MI, Eq. 1) and the chromosomal aberration index (CAI, Eq. 3) according to methodology described by Lima et al. (Lima et al. 2012). These images were collected using an optical microscope (Olympus, model BX 50 DP2BSW). The relative mitotic index ${ }^{2}$ (RMI, Eq. 2) and relative chromosomal aberration index (RCAI, Eq. 4) are obtained in relation to the negative control and generally used in graphs for better visualization.

$\mathrm{MI}=\left(\frac{\text { Total number of cells in division }}{\text { Total observed cells }}\right) \times 100$

$\mathrm{RMI}=\left(\frac{\mathrm{MI}}{\text { MI negative control }}\right)$

$\mathrm{CAI}=\left(\frac{\text { Total number of altered cells }}{\text { Total observed cells }}\right) \times 100$

$R C A I=\frac{\mathrm{CAI}}{\mathrm{CAI} \text { negative control }}$

Statistical analysis

Results of cytotoxicity and genotoxicity assays were analyzed using the BioEstat 5.8.3.0 software (AnalystSoft) through the non-parametric Mann-Whitney test, intended to compare two independent samples and one variable. The statistical significance analysis was defined as $p<0.05$ (Christofoletti, Pedro-Escher, Fontanetti 2013).

\footnotetext{
${ }^{1}$ Mitotic index is the percentage of cells found in one of the four mitosis phases.

${ }^{2}$ Relative mitotic index indicates alterations observed in root growth induced by the tested substance (or material) compared to the negative control.
} 


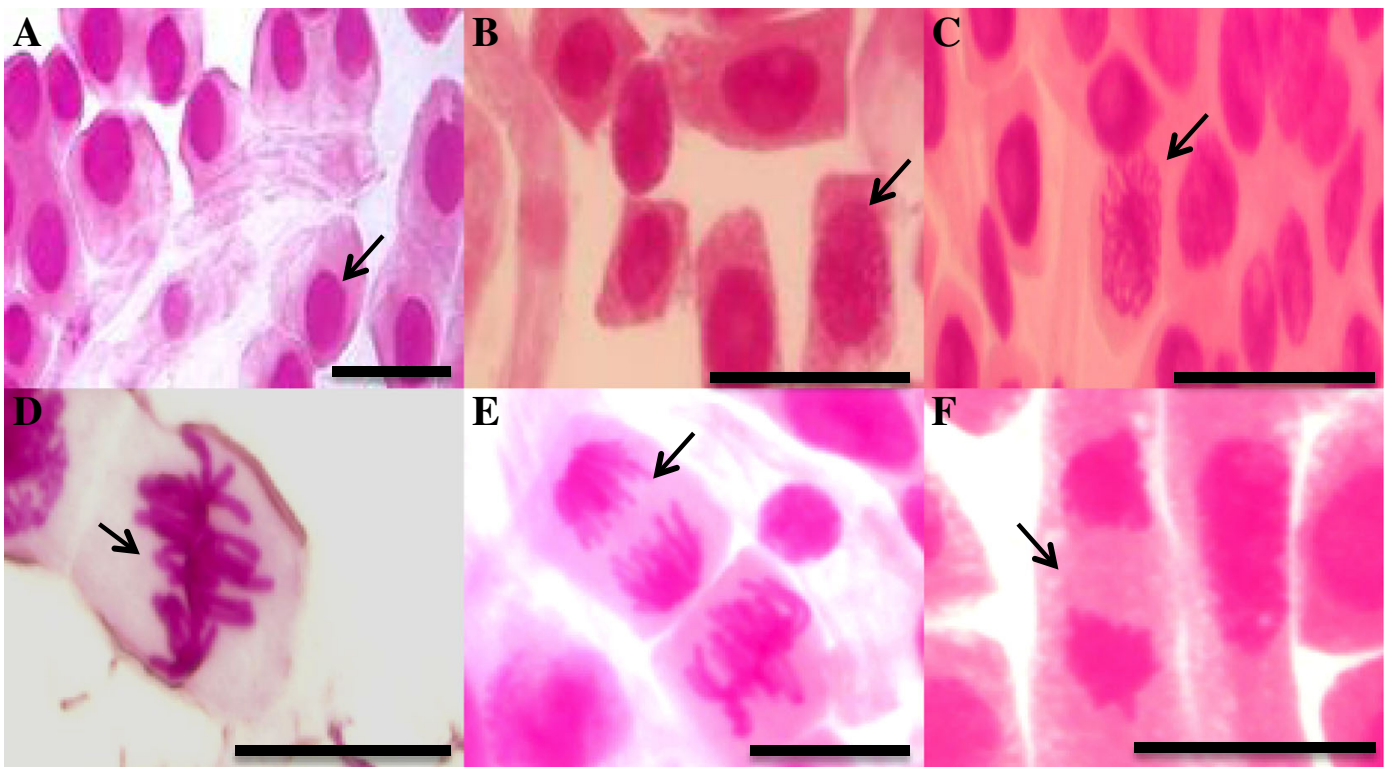

Fig. 1 Normal A. cepa meristematic cells. a Interphase (arrow). b, c Prophase (arrow). d Metaphase (arrow). e Anaphase (arrow). f Telophase (arrow). Scale bar-10 $\mu \mathrm{m}$

\section{Results and discussion}

Test 1: effect of silver nanoparticles in the absence of $\mathrm{CMC}$

After the treatments, the cells at the different phases (i.e., prophase, metaphase, anaphase, and telophase) of the cell division cycle (Fig. 1) as well as the number of cells carrying chromosomal aberrations (Fig. 4) were counted and used to calculate the MI (Eq. 1), RMI (Eq. 2) (Table 3), CAI (Eq. 3), and RCAI (Eq. 4) (Table 2).

Table 1 and Fig. 2 show the results obtained for the MI and RMI analyses in A. cepa cells after $24 \mathrm{~h}$ of exposure in AgNP-containing solutions. Table 1 shows that MI was inferior to concentration A, presenting a value of 5.01 .
Regardless of the tested concentrations (1.50 and $15.00 \mathrm{ppm})$, a cytotoxic effect was induced upon the exposure to nanoparticles, as indicated by the significant reduction of MI of treated cells when compared to the negative control ( $p=0.01$ and $p=0.04$, respectively) (Fig. 2). According to some authors, the cytotoxicity of AgNPs may occur due to the generation of ROS, fact observed in the study of Cvjetko et al. 2017.

Increase of nanoparticle concentration led to an independent enhance in MI, although Kumari et al. (2009), when studying different AgNP concentrations $(25,50,75$, and $100 \mathrm{ppm})$, reported that the cytotoxic effect is dependent on the increase in concentration. Some authors have demonstrated that alterations in the number of cell division occur due to the modifications caused by the mitotic cycle duration time with an

Table 1 Mitotic index (MI) and relative mitotic index (RMI) of A. cepa meristematic cells for two concentrations of the tested substance, negative control and positive control

\begin{tabular}{|c|c|c|c|c|}
\hline Samples & $\begin{array}{l}\text { Number of analyzed } \\
\text { cells }\end{array}$ & $\begin{array}{l}\text { Mean and SD of cells } \\
\text { in division }\end{array}$ & MI (\%) & RMI \\
\hline Negative control & 5235 & $194 \pm 52$ & 14.10 & 1.1 \\
\hline Positive control & 5182 & $148 \pm 20$ & 13.33 & 1.0 \\
\hline $\mathrm{A}(1.50 \mathrm{ppm})$ & 5058 & $43 \pm 16$ & $5.01 *$ & 0.4 \\
\hline B (15.00 ppm) & 5572 & $59 \pm 22$ & $6.40 *$ & 0.5 \\
\hline
\end{tabular}

*Statistically significant $(p<0.05)$ in relation to the negative control 


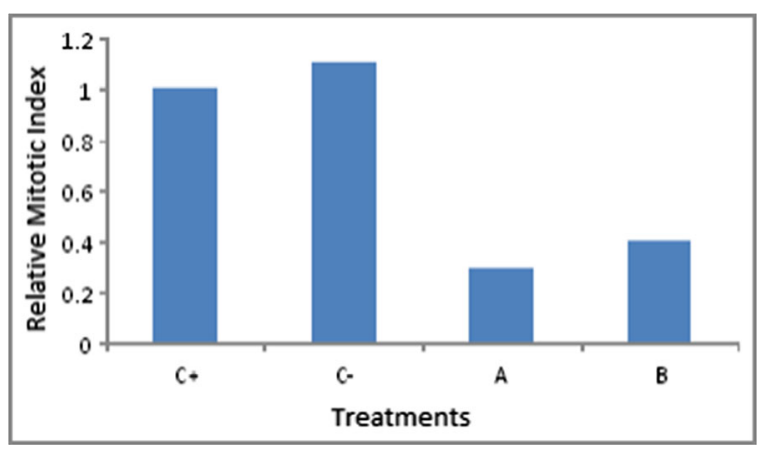

Fig. 2 Different treatments effect in relative mitotic index (RMI) in A. cepa cells, where $\mathrm{C}^{+}$is trifluralin $0.075 \mathrm{~g} / \mathrm{L}, \mathrm{C}^{-}$is ultrapure water, $A$ is $1.50 \mathrm{ppm}$ silver nanoparticle, and $B$ is $15.00 \mathrm{ppm}$ silver nanoparticle

extension of the cell division S phase (Macleod 1969; Webster and Davidson 1969).

Like cytotoxic effects, significant DNA damages were also observed, as suggested by the comparison of CAI and RCAI values (Table 2 and Fig. 3 ) with those of the negative control, which characterizes genotoxic effect. However, this effect was only statistically significant for concentration A $(p=0.006)$ and was not observed for concentration B $(p=0.06)$. The CAI value of concentration $\mathrm{B}(2.0)$ was higher than that of the positive control (1.61), indicating a remarkable AC induction to concentration B. Nonetheless, the non-significant results may be associated with the standard deviation around the average value. The average number of CAs (chromosomal alterations) found for concentration A (26.80) was considerably higher than the value obtained for concentration B (17.20).

The CA types and amounts found after exposition are presented in Fig. 4. According to (Barbério 2013), contaminants can cause two alteration types: clastogenic, characterized by the breakdown of genetic material (bridges, for instance) and aneugenic, typified by compromising chromosome segregation throughout cell division (C-metaphase and adhesion, to mention a few).

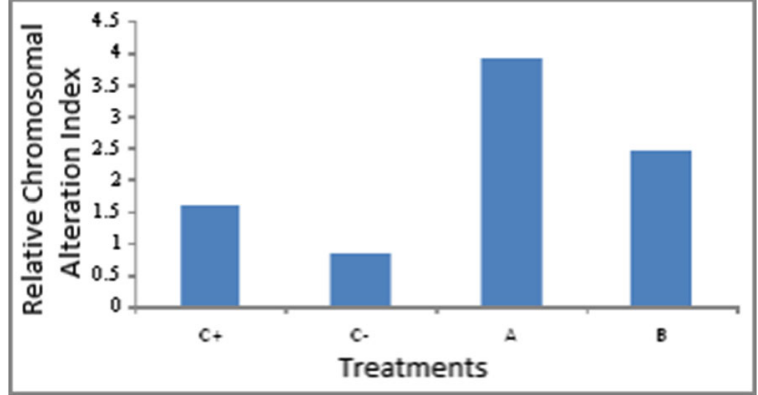

Fig. 3 Effects of different treatments on the relative chromosomal alteration index (RCAI) of $A$. cepa cells, where $\mathrm{C}^{+}$is trifluralin $0.075 \mathrm{~g} \mathrm{~L}, \mathrm{C}^{-}$is ultrapure water, $A$ is $1.5 \mathrm{ppm}$ of silver nanoparticles, and $B$ is $15 \mathrm{ppm}$ of silver nanoparticles

As shown in Fig. 4, CAs of both clastogenic (bridges) and aneugenic (chromosomal loss, C-metaphase, and chromosomal adhesion) types were observed.

The modification known as C-metaphase (Fig. 4e), according to (Fernandes et al. 2007), can result from the action of aneugenic agents that promote complete inactivation of mitotic cycle. This alteration, in turn, may generate alterations such as polypoid, multinucleate, and micronuclei cells (Kirsch-Volders et al. 2002). In accordance with Kuriyama and Sakai (1974), the mitotic cycle is impaired by the interaction between AgNPs and tubulin-SH groups.

Chromosomal bridges (Fig. 4b) can result from chromosomal adhesion (Fig. 4h), which in certain cases could be multiples and persist until telophase (Marcano et al. 2004). According to Kumari et al. (2009), chromosomal adhesion can be related to the effect caused by extrachromosomal intertwining of the chromatin fibers. The presence of this alteration is evidence of toxic effect and is considered irreversible.

Chromosomal fragments (Fig. 4b) could result from the interruption of chromosomal bridges (Fiskejo 1993), being chromosomal breakages (Fig. 4d, i) and micronuclei (MN) (Fig. 4c) excellent mutagenicity

Table 2 Chromosomal alteration index (CAI), and relative chromosomal alteration index (RCAI) of $A$. cepa meristematic cells for two concentrations of tested substance, negative and positive controls

\begin{tabular}{llccc}
\hline Samples & Number of analyzed cells & Mean and SD of altered cells & CAI \% & RCAI \\
\hline Negative control & 5235 & $8.4 \pm 3.9$ & 0.85 & 1.0 \\
Positive control & 5182 & $16.8 \pm 4.1$ & $3.61^{*}$ & $2.0^{*}$ \\
A (1.50 ppm) & 5058 & $26.8 \pm 13.9$ & $3.9^{*}$ \\
B (15.00 ppm) & 5572 & $17.2 \pm 11.7$ & 2.0 & 2.4 \\
\hline
\end{tabular}

* Statistically significant $(p<0.05)$ compared to the negative control 


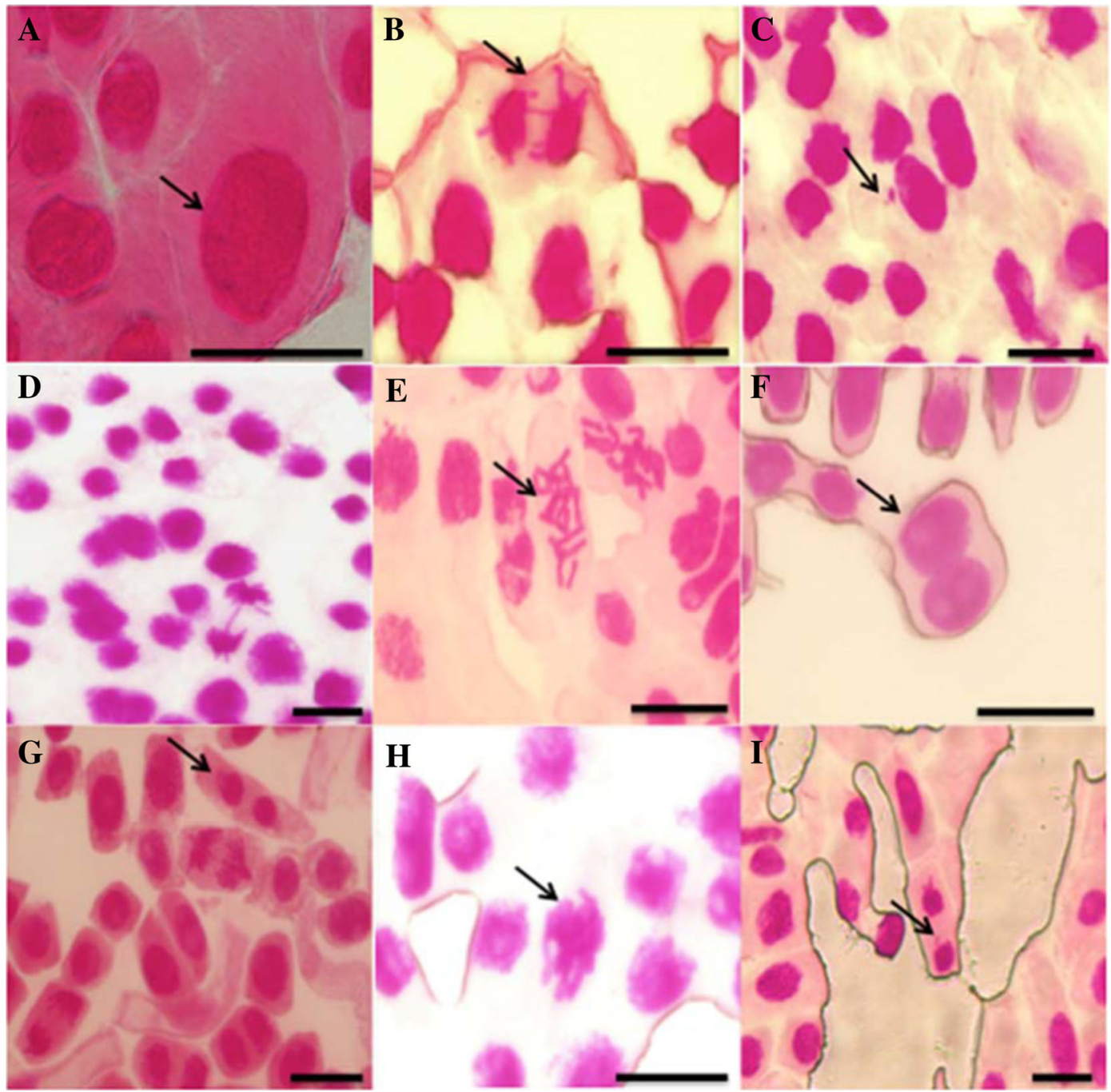

Fig. 4 Chromosomal aberrations found in A. cepa meristematic cells after exposure to AgNPs. a Polypoid cells (arrow). b Anaphase with bridge and chromosomal fragment (arrow). c Cell with micronuclei. d Belated anaphase and chromosomal fracture. e C-

metaphase. f Binuclear cell. g Telophase with sprout (arrow). h Cell with chromosomal adhesion (arrow). i telophase with chromosomal fracture (arrow). Scale bar-10 $\mu \mathrm{m}$

endpoints. Because such genetic material amendments cannot be repaired by cells, these may, therefore, be transmitted to new cell generations (De Campos

Ventura et al. 2008). Consequently, $\mathrm{MN}$ are rarely reincorporated to chromosomal set after division by the mitotic cycle inactivation (aneugenic event-loss of

Table 3 Mitotic index (MI) and relative mitotic index (RMI) of A. cepa meristematic cells for both concentrations of the tested substance, negative control and positive control

\begin{tabular}{|c|c|c|c|c|}
\hline Samples & Number of analyzed cells & Mean and SD of altered cells & MI (\%) & RMI \\
\hline Negative control & 5235 & $132.1 \pm 35.3$ & 13.3 & 1.0 \\
\hline Positive control & 5182 & $148.2 \pm 28.8$ & 14.2 & 1.1 \\
\hline C1 (1.24 ppm Ag) & 5157 & $114.1 \pm 35.1$ & 11.1 & 0.8 \\
\hline $\mathrm{C} 2(12.40 \mathrm{ppm} \mathrm{Ag})$ & 5203 & $97.4 \pm 20.3$ & 9.28 & 0.7 \\
\hline
\end{tabular}




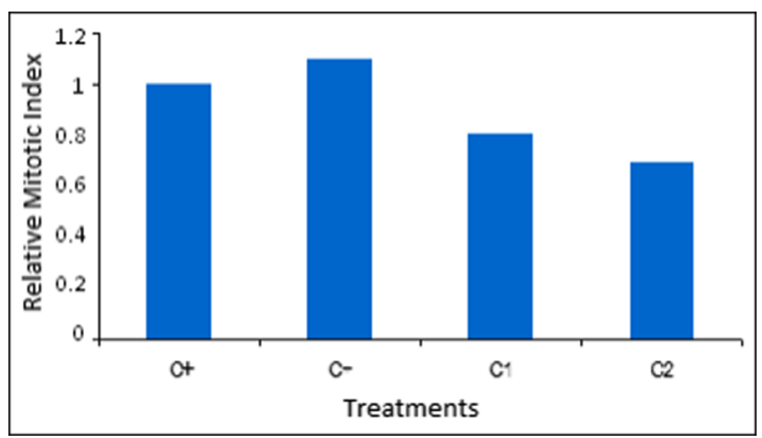

Fig. 5 Effect of different treatments on the relative mitotic index (RMI) of A. cepa cells, where $\mathrm{C}^{+}$is trifluralin $0.075 \mathrm{~g} / \mathrm{L}, \mathrm{C}^{-}$is ultrapure water, $\mathrm{C} 1$ is CMC/AgNP-PVA $1.24 \mathrm{ppm} \mathrm{Ag}$, and $\mathrm{C} 2$ is CMC/AgNP-PVA 12.40 ppm Ag

entire chromosomes) or chromosomal breakages (clastogenic events-loss of acentric fragments) (Fenech 2000). The induction of chromosomal breakages by AgNP indicates its clastogenic potential, which may engender the loss of genetic material (Cuicai et al. 1992).

Kumari et al. (2009) and Nair et al. (2010) reinforced the need for evaluating the potential citotoxic and genotoxic effects of AgNPs, taking into account nanoparticle properties (absorption, distribution, and translocation) in plant cell tissues. For instance, in certain plants, few negative effects are observed, including plant biomass and transpiration decreases. These outcomes were observed by Stampoulis et al. (2009) when studying the germination and growth of squash seeds in a AgNP-containing hydroponic solution. In contrast, effects related to necrosis, senescence, and cellular death are also noticed in plants as a result of the effect caused by the presence of $\mathrm{Ag}^{+}$(Navabpour et al. 2003).

In 2011, Park et al. (2011) verified that the citotoxic and genotoxic effects of AgNPs are correlated with their sizes, which results corroborate with the findings reported by Lima et al. (2013): AgNPs of $20 \mathrm{~nm}$ in diameter

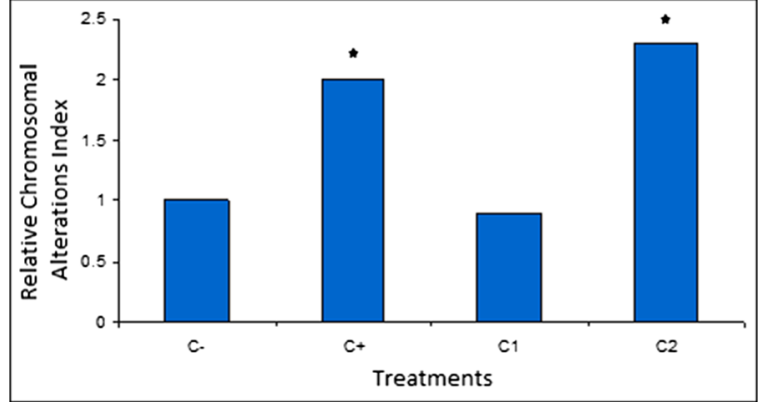

Fig. 6 Effect of different treatments in the relative chromosomal alteration index (RCAI) of $A$. cepa cells, where $\mathrm{C}^{+}$is triflurin $0.075 \mathrm{~g} / \mathrm{L}, \mathrm{C}^{-}$is ultrapure water, $\mathrm{C} 1$ is CMC/AgNP-PVA $1.24 \mathrm{ppm} \mathrm{Ag}$, and $\mathrm{C} 2$ is CMC/AgNP-PVA $12.40 \mathrm{ppmAg}$. * Statistically significant $(p<0.05)$ compared to the negative control

showed more toxic effects than their counterparts with diameters from 80 to $113 \mathrm{~nm}$.

Test 2: analysis of silver nanoparticle effects in the presence of the polymer CMC

The cytotoxicity assessment tests did not indicate cell death induction. Taking the relative mitotic index calculations into account, no cytotoxic action of the AgNPcontaining samples was observed. Therefore, the indices were not significantly decreased (Table 3 and Fig. 5).

Genotoxic effect analysis pointed out significant results after the exposure of $A$. cepa seeds to the herbicide trifluralin and to the highest tested AgNP-PVA concentration (Table 4 and Fig. 6).

Using A. cepa as a test organism for evaluating the cytotoxic and genotoxic effects of CMC/(AgNP-PVA) film-forming solutions allowed us to detect significant results for the highest AgNP-PVA concentration, which led to an enhanced chromosomal alteration index. Nonetheless, the lowest AgNP-PVA concentration caused no significant alterations when compared to the negative control, indicating that these materials were less toxic

Table 4 Chromosomal alteration index (CAI) and relative chromosomal alteration index (RCAI) of $A$. cepa meristematic cells for both tested substance concentrations, negative control and positive control

\begin{tabular}{|c|c|c|c|c|}
\hline Samples & Number of analyzed cells & Mean and SD of altered cells & CAI \% & RCAI \\
\hline Negative control & 5235 & $8.4 \pm 3.9$ & 0.82 & 1.0 \\
\hline Positive control & 5182 & $16.8 \pm 4.1$ & $1.61 *$ & $2.0^{*}$ \\
\hline C1 (1.24 ppm Ag) & 5157 & $7.5 \pm 3.4$ & 0.72 & 0.9 \\
\hline C2 (12.40 ppm Ag) & 5203 & $19.6 \pm 4.5$ & $1.92 *$ & $2.3 *$ \\
\hline
\end{tabular}

*Statistically significant $(p<0.05)$ compared to the negative control 
Fig. 7 Chromosomal aberrations in A. cepa meristematic cells upon exposure to film-forming solutions containing silver nanoparticles. a Anaphase with bridge. b Telophase with bridge. c Cell with micronuclei. Scale bar $-10 \mu \mathrm{m}$

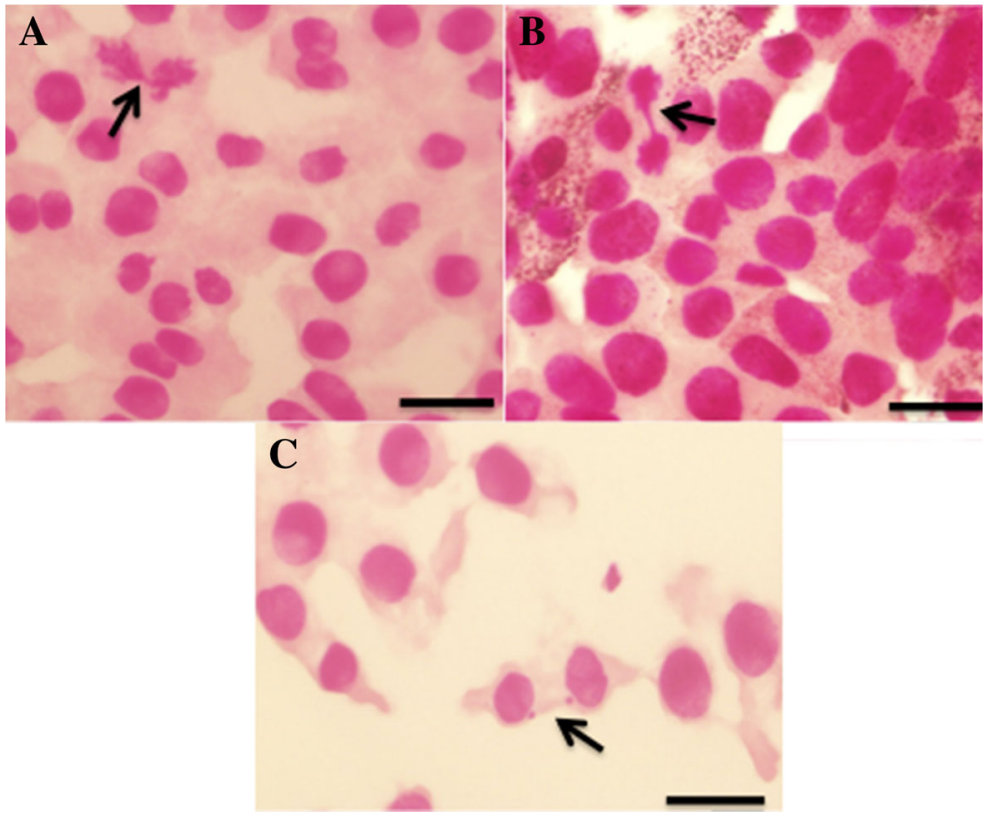

$12.40 \mathrm{ppm}$ of $\mathrm{AgNp}$ in the presence of CMC. The toxicity demonstrated here may interfere in intracellular components and lead to several problems during cell division. Because of the possibility of inducing harmful effects to the genetic material of the studied organism, the results indicate that, depending on the concentration and the combination with distinct materials, AgNP can be detrimental to the environment, which requires the control of the disposal of materials and packaging containing silver nanoparticles.

Acknowledgments The authors acknowledge MCTI/SISNANO, CNPq, FAPESP, CAPES, and Embrapa-Rede Agronano for the financial support. The experimental assistance of Dr. Jaqueline Bianchi Ambrósio and Dr. Marcos Arduin is also acknowledged.

\section{References}

Anacleto, L. R., Roberto, M. M., \& Marin-Morales, M. A. (2017). Toxicological effects of the waste of the sugarcane industry, used as agricultural fertilizer, on the test system Allium cepa. Chemosphere, 173, 31-42.

Barberio, A. (2013). Bioassays with plants in the monitoring of water quality. In W. Elshorbagy (Ed.), Water treatment (pp. 317-334). doi:10.5772/50546.Intech.Available from $\mathrm{http}: / / w w w . i n t e c h o p e n . c o m / b o o k s / w a t e r-t r e a t m e n t / b i o a s s a y s-$ with-plants-in-the-monitoring-of-water-quality.

Becaro, A. A., Jonsson, C. M., Puti, F. C., Siqueira, M. C., Mattoso, L. H. C., Correa, D. S., Ferreira, M. D. (2015). Toxicity of PVAstabilized silver nanoparticles to algae 
and microcrustaceans. Environmental Nanotechnology, Monitoring \& Management, 3, 22-29. doi:10.1016/j. enmm.2014.11.002.

Becaro, A. A., Puti, F. C., Correa, D. S., Paris, E. C., Marconcini, J. M., \& Ferreira, M. D. (2015). Polyethylene films containing silver nanoparticles for applications in food packaging: characterization of physico-chemical and anti-microbial properties. Journal of Nanoscience and Nanotechnology, 15, 2148-2156.

Becaro, A. A., Puti, F. C., Panosso, A. R., Gern, J. C., Brandão, H. M., Correa, D. S., \& Ferreira, M. D. (2016). Postharvest quality of fresh-cut carrots packaged in plastic films containing silver nanoparticles. Food and Bioprocess Technology, 9, 637-649.

Belcavello, L., Cunha, M. R. H., Andrade, M. A., \& Batitucci, M. D. C. P. (2012). Citotoxicidade e danos ao DNA induzidos pelo extrato de Zornia diphylla, uma planta medicinal. Natureza on line, 10(3), 140-145.

Caritá, R., \& Marin-Morales, M. A. (2008). Induction of chromosome aberrations in the Allium cepa test system caused by the exposure of seeds to industrial effluents contaminated with azo dyes. Chemosphere, 72, 722-725.

Christofoletti, C. A., Pedro-Escher, J., \& Fontanetti, C. S. (2013). Assessment of the genotoxicity of two agricultural residues after processing by diplopods using the Allium cepa assay. Water, Air, and Soil Pollution, 224, 1523.

Cuicai, R., Yuan, L., \& Jinling, L. (1992). Application of micronuclues test in Vicia faba root tips in the rapid detection of mutagenic environmental pollutants. Environmental Science, 4, 15.

Cvjetko, P., Milošića, A., Domijan, A.-M., Vrčekc, I. V., Tolićd, S., Štefanića, P. P., Letofsky-Papste, I., Tkaleca, M., \& Balena, B. (2017). Toxicity of silver ions and differently coated silver nanoparticles in Allium cepa roots. Ecotoxicology and Environmental Safety, 137, 18-28.

De Campos Ventura, B., De Angelis, D. D. F., \& Marin-Morales, M. A. (2008). Mutagenic and genotoxic effects of the Atrazine herbicide in Oreochromis niloticus (Perciformes, Cichlidae) detected by the micronuclei test and the comet assay. Pesticide Biochemistry and Physiology, 90(1), 42-51.

Deng, F., Wang, S., \& Xin, H. (2016). Toxicity of CuO nanoparticles to structure and metabolic activity of Allium cepa root tips. Bulletin of Environmental Contamination and Toxicology, 97, 702-708.

Derbalah, A. S., Elkot, G. A. E., \& Hamza, A. M. (2011). Laboratory evaluation of botanical extracts, microbial culture filtrates and silver nanoparticles against Botrytis cinerea. Annales de Microbiologie. doi:10.1007/s13213-011-0388-1.

Fenech, M. (2000). The in vitro micronucleus technique. Mutation Research/Fundamental and Molecular Mechanisms of Mutagenesis, 455(1), 81-95.

Fernandes, T. C., Mazzeo, D. E. C., \& Marin-Morales, M. A. (2007). Mechanism of micronuclei formation in polyploidizated cells of Allium cepa exposed to trifluralin herbicide. Pesticide Biochemistry and Physiology, 88(3), 252-259.

Fiskesjö, G. (1985). The Allium test as a standard in environmental monitoring. Hereditas, 102(1), 99-112.

Fiskejo, G. (1993). Allium test I: a 2-3 day plant test for toxicity assessment by measuring the mean root growth of onions (Allium cepa L.) Environmental Toxicology and Water Quality, 8(4), 461-470.
Gambardella, C., Aluigi, M. G., Fernando, S., Gallus, L., Ramoino, P., Gatti, A. M., Rottigni, M., \& Falugi, C. (2013). Developmental abnormalities and changes in cholinesterase activity in sea urchin embryos and larvae from sperm exposed to engineered nanoparticles. Aquatic Toxicology, 130, 77-85.

Hebeish, A., Hashem, M., El-hady, M. M. A., \& Sharaf, S. (2013). Development of CMC hydrogels loaded with silver nanoparticles for medical applications. Carbohydrate Polymers, 92, 407-413.

Juchimiuk, J., \& Maluszynska, J. (2005). Transformed roots of Crepis capillaries - a sensitive system for the evaluation of the clastogenicity of abiotic agents. Mutation Research/ Genetic Toxicology and Environmental Mutagenesis, 565(2), 129-138.

Kanmani, P., \& Rhim, J.-W. (2014). Physical, mechanical and antimicrobial properties of gelatin based active nanocomposite films containing AgNPs and nanoclay. Food Hydrocolloids, 35, 644-652.

Kirsch-Volders, M., Vanhauwaert, A., De Boeck, M., \& Decordier, I. (2002). Importance of detecting numerical versus structural chromosome aberrations. Mutation Research/Fundamental and Molecular Mechanisms of Mutagenesis, 504(1), 137148.

Kumari, M., Mukherjee, A., \& Chandrasekaran, N. (2009). Genotoxicity of silver nanoparticles in Allium cepa. Science of the Total Environment, 407(19), 5243-5246.

Kumari, M., Khan, S. S., Pakrashi, S., Mukherjee, A., \& Chandrasekaran, N. (2011). Cytogenetic and genotoxic effects of zinc oxide nanoparticles on root cells of Allium cepa. Journal of Hazardous Materials, 190(1), 613-621.

Kuriyama, R., \& Sakai, H. (1974). Role of tubulin-Sh groups in polymerization to microtubules functional-Sh groups in tubulin for polymerization. Journal of Biochemistry, 76(3), 651-654.

Leme, D. M., \& Marin-Morales, M. A. (2008). Chromosome aberration and micronucleus frequencies in Allium cepa cells exposed to petroleum polluted water-a case study. Mutation Research/Genetic Toxicology and Environmental Mutagenesis, 650(1), 80-86.

Leme, D. M., \& Marin-Morales, M. A. (2009). Allium cepa test in environmental monitoring: a review on its application. Mutation Research, 682, 71-81.

Lima, R., Feitosa, L. O., Maruyama, C. R., Barga, M., Yamawaki, P. C., Vieira, I. J., Teixeira, E. M., Correa, A. C., Mattoso, L. H. C., \& Fracetto, L. F. (2012). Evaluation of the genotoxicity of cellulose nanofibers. International Journal of Nanomedicine, 7, 3555-3565.

Lima, R., Feitosa, L. O., Ballottin, D., Marcato, P. D., Tasic, L., \& Durán, N. (2013). Cytotoxicity and genotoxicity of biogenic silver nanoparticles (pp. 1-7). Conference Series: Journal of Physics.

Ma, T.-H., Xu, Z., Xu, C., McConnell, H., Rabago, E. V., Arreola, G. A., \& Zhang, H. (1995). The improved Allium/Vicia root tip micronucleus assay for clastogenicity of environmental pollutants. Mutation Research/Environmental Mutagenesis and Related Subjects, 334(2), 185-195.

Macleod, R. (1969). Some effects of 2, 4, 5-trichlorophenoxyacetic acid on the mitotic cycle of lateral root apical meristems of Vicia faba. Chromosoma, 27(3), 327-337. 
Marcano, L., Carruyo, I., Del Campo, A., \& Montiel, X. (2004). Cytotoxicity and mode of action of maleic hydrazide in root tips of Allium cepa L. Environmental Research, 94(2), 221-226.

Marsh, K., \& Bugusu, B. (2007). Food packaging - roles, materials, and environmental issues. Journal of Food Science, 72(3), 39-55.

Mateuca, R., Lombaert, N., Aka, P. V., Decordier, I., \& KirschVolders, M. (2006). Chromosomal changes: induction, detection methods and applicability in human biomonitoring. Biochimie, 88(11), 1515-1531.

Mayachiew, P., \& Devahastin, S. (2010). Effects of drying methods and conditions on release characteristics of edible chitosan films enriched with Indian gooseberry extract. Food Chemistry, 118(3), 594-601.

Mazzeo, D. E. C., Fernandes, T. C. C., Levy, C. E., Fontanetti, C. S., \& Marin-Morales, M. A. (2015). Monitoring the natural attenuation of a sewage sludge toxicity usingthe Allium cepa test. Ecological Indicators, 56, 60-69.

Mbhele, Z. H., Salemane, M. G., Sittert, C. G., Nedeljkovic, J. M., Djokovic, V., \& Luyt, A. S. (2003). Fabrication and characterization of silverpolyvinyl alcohol nanocomposites. Chemistry of Materials, 15(26), 5019-5024.

Moura, M. R., Lorevice, M. V., Mattoso, L. H. C., \& Zucolotto, V. (2011). Highly stable, edible cellulose films incorporating chitosan nanoparticles. Journal of Food Science, 76(2), 25-29.

Nair, R., Varghese, S. H., Nair, B. G., Maekawa, T., Yoshida, Y., \& Kumar, D. S. (2010). Nanoparticulate material delivery to plants. Plant Science, 179(3), 154-163.

Navabpour, S., Morris, K., Allen, R., Harrison, E., A-HMackerness, S. A., \& Wollaston, V. B. (2003). Expression of senescence-enhanced genes in response to oxidative stress. Journal of Experimental Botany, 54(391), 2285-2292.

Neto, E. A. B., Ribeiro, C., \& Zucolotto, V. (2008). Sintese de Nanoparticulas de Prata para Aplicacao na Sanitizacao de Embalagens. Comunicado Tecnico, Sao Carlos, 1, 1-4.

Pakrashi, S., Jain, N., Dalai, S., Jayakumar, J., Chandrasekaran, P. T., Raichur, A. M., Chandrasekaran, N., \& Mukherjee, A. (2014). In vivo genotoxicity assessment of titanium dioxide nanoparticles by Allium cepa root tip assay at high exposure concentrations. PloS One, 9(2), e87789.

Panda, K. K., Aachary, V. M. M., Krishnaveni, R., Padhj, B. K., Sarangi, S. N., Sahu, S. N., \& Panda, B. B. (2011). In vitro biosynthesis and genotoxicity bioassay of silver nanoparticles using plants. Toxicology In Vitro, 25(5), 1097-1105.

Park, M. V., Neigh, A. M., Vermeulen, J. P., de la Fonteyne, L. J., Verharen, H. W., Briedé, J. J., van Loveren, H., \& de Jong, W. H. (2011). The effect of particle size on the cytotoxicity, inflammation, developmental toxicity and genotoxicity of silver nanoparticles. Biomaterials, 32(36), 9810-9817.

Patlolla, A. K., Berry, A., May, L., \& Tchounwou, P. B. (2012). Genotoxicity of silver nanoparticles in Vicia faba: a pilot study on the environmental monitoring of nanoparticles. International Journal of Environmental Research and Public Health, 9(5), 1649-1662.

Pulate, P. V., Ghurde, M. U., \& Deshmukh, V. R. (2011). Cytological effect of the biological and chemical silver nanoparticle in Allium cepa. International Journal of Innovations in Bio-Sciences, 1, 32-35.

Qin, R., Ning, C., Björn, L. O., \& Li, S. (2016). Proteomic analysis of Allium cepa var. agrogarum L. roots under copper stress. Plant and Soil, 401, 197-212.
Rajeshwari, A., Roy, B., Chandrasekaran, N., \& Mukherjee, A. (2016). Cytogenetic evaluation of gold nanorods using Allium cepa test. Plant Physiology and Biochemistry, 109, 209-219.

Rodríguez, Y. A., Christofoletti, C. A., Pedro, J., Bueno, O. C., Malaspina, O., Ferreira, R. A. C., \& Fontanetti, C. S. (2015). Allium cepa and Tradescantia pallida bioassays to evaluate effects of the insecticide imidacloprid. Chemosphere, 120, 438-442.

Satapathy, R., \& Swamy, P. (2013). Preparative isolation of flavonoids 515 from Wattakaka volubilis (linn. f.) leaf extracts and its role as 516 antimitotic and antiproliferating agent. International Journal of Pharma and Bio Sciences, 4, 517(3), 454-460.

Shin, S.-H., Kim, S.-J., Lee, S.-H., Park, K.-M., \& Han, J. (2014). Apple peel and carboxymethylcellulose-based nanocomposite films containing different nanoclays. Journal of Food Science, 79, 342-353.

Siqueira, M. C., Coelho, G. F., Moura, M. R., Bresolin, J. D., Hubinger, S. Z., Marconcini, J. M., \& Mattoso, L. H. C. (2014). Evaluation of antimicrobial activity of silver nanoparticles for carboxymethylcellulose film applications in food packaging. Journal of Nanoscience and Nanotechnology, 14, 5512-5517.

Sobeh, S.S., Kheiralla, Z.M.H., Rushdy, A.A. \& Yakob, N.A.N. (2016). In vitro and in vivo genotoxicity and molecular response of silver nanoparticles on different biological model systems. 69(2), 147-161.

Stampoulis, D., Sinha, S. K., \& White, J. C. (2009). Assaydependent phytotoxicity of nanoparticles to plants. Environmental Science \& Technology, 43(24), 9473-9479.

Su, C.-K., Liu, H.-T., Hsia, S.-C., \& Sun, Y.-C. (2014). Quantitatively profiling the dissolution and redistribution of silver nanoparticles in living rats using a knotted reactor-based differentiation scheme. Analytical Chemistry, 86, 8267-8274.

Turkoglu, S. (2012). Determination of genotoxic effect s of chlorfenvinphos and fenbuconazole in Allium cepa root cells by mitotic activity, chromosome aberrantion, DNA content, and comet assay. Pesticide Biochemistry and Physiology, 103, 224-230.

Vargasa, J. T., Rodríguez-Monroya, M., Meyerc, M. L., MontesBelmontb, R., \& Sepúlveda-Jiméneza, G. (2017). Trichoderma asperellum ameliorates phytotoxic effects of copper in onion (Allium cepa L.) Environmental and Experimental Botany, 136, 85-93.

Webster, P., \& Davidson, D. (1969). Changes in the duration of the mitotic cycle induced by colchicine and indol-3yl-acetic acid in Vicia faba roots. Journal of Experimental Botany, 20(3), 671-685.

White, P. A., \& Claxton, L. D. (2004). Mutagens in contaminated soil: a review. Mutation Research/Reviews in Mutation Research, 567(2), 227-345.

Yu, L., Lu, H., \& Liu, Q. (2013). Ultrafine silver nanoparticles with excellent antibacterial efficacy prepared by a handover of vesicle templating to micelle stabilization. Polymer Chemistry, 4, 3448-3452.

Zhu, C., Mills, K. D., Ferguson, D. O., Lee, C., Manis, J., Fleming, J., Gao, Y., Morton, C. C., \& Alt, F. W. (2002). Unrepaired DNA breaks in p53-deficient cells lead to oncogenic gene amplification subsequent to translocations. Cell, 109, 811-821. 